Lo Bianco, Joseph (2004) Language Planning as Applied Linguistics. In A. Davies \& C. Elder (Eds)

Handbook of Applied Linguistics (pp. 738-762). Malden, MA: Blackwell Publishing Ltd

(C) 2004 by Blackwell Publishing Ltd

All rights reserved. No part of this publications may be reproduced, stored in a retrieval system, or transmitted, in any form or by any means, electronic, mechanical, photocopying, recording or otherwise, except as permitted by the UK Copyright, Designs, and Patents Act 1988, without the prior permission of the publisher.

\title{
Language Planning as Applied Linguistics
}

\section{Joseph Lo Bianco}

\section{Introduction}

I take the theme of this volume to be that a distinction between applied linguistics and linguistics applied is useful and necessary and argue that scholarship on language policy and planning (hereafter LPP) substantiates this distinction and bolsters claims that applied linguistics is a coherent and distinctive academic discipline not dependent on formal linguistics (Brumfit, 1997; Davies, 1999). The main reason for this claim is that the practical nature of the problems that LPP deals with requires us to analyze specificities of policy-making in contexts where language is only a part. The abstractions of descriptive linguistics, and the abstractions of those kinds of applied linguistics that imagine a descent lineage from descriptive linguistics, and, further, the abstractions of those branches of sociolinguistics that derive conceptually from descriptive linguistics, lead to models for studying language planning that are weakly descriptive, a-social, and a-historical. Language problems always arise in concrete historical contexts and these inevitably involve rival interests reflecting "loaded" relations among ethnic, political, social, bureaucratic, and class groupings, and other kinds of ideological splits and controversies, including personal ones. To explain how language problems encapsulate or exacerbate such relations requires interdisciplinary research grounded in real-world data. Understood in this way, as a scholarly practice deeply embedded in sociology, history, ethnic relations, politics, and economics, LPP research is applied scholarship drawing on knowledge far beyond linguistics. The extent to which LPP draws on descriptive linguistics varies according to the kind of language planning activity being studied, and the particular tradition of linguistic description which is utilized.

However, studying and doing language planning also poses challenges to applied linguistics. A key challenge derives from the policy infused nature of knowledge (data, concepts, and relationships) that informs language policy-making processes. An "interested" or "motivated" character is inherent in LPP and needs to be theorized as a central feature of researching language policy. An early aspiration of language planning scholars for a science of the field - "Language planning as a rational and technical process informed by actuarial data and by ongoing feedback is still a dream, but it is by no means so farfetched a dream as it seemed to be merely a decade ago" (Fishman, 1971, p. 111) has had to be discarded as all the human sciences acknowledge, if not enjoy, the philosophical logic of postmodernity with its insistence on the impossibility of interest-free knowledge. Research conducted to sustain policy development is organically invested with dilemmas about how knowledge designed for action, for application, in contexts of contending interests and ideologies, is implicated in these processes and cannot in any absolute sense rise above interests and ideology. This does not mean that "rational and technical" processes are not possible, just that we must theorize these in the context of persisting interests. There is an almost complete lack of use of categories drawn from descriptive linguistic classification in actual policy-making, with the possible exception of some corpus 
planning work. Even applied linguistics, and indeed, even trained professional language planners and the body of knowledge that might be called language planning theory, are rarely called upon, as Fishman has noted "... very little language planning practice has actually been informed by language planning theory" (1994, p. 97).

Despite all this, LPP is probably the most dispersed practice of applied linguistics and as old as verbalized semiotics: universal and ancient. That public authorities make minimal use of scholarly studies of language problems in society is a contradiction addressed throughout this chapter. Perversely, it is not only the actual practice of language policy-making that neglects LPP theory and scholarship, but also some theorizations of applied linguistics and sociolinguistics. For example, Chambers' Sociolinguistic Theory (1995) reserves "sociolinguistics" essentially for variation theory and removes LPP out of language studies altogether, placing it under political science. Even in academic programs that include LPP studies it is marginal, underscoring Kaplan's observation that "... only a handful of universities in the world offers anything more than a random course in language policy/planning" (1994, p. 3).

\section{Defining and Theorizing}

A continuing search for an adequate definition in LPP writing reflects both the wide range of disciplines that inform the field and the diversity of activity that is called language planning. During its formative decades of the 1960s and 1970s language planning theory tried to be a "science," understanding "science" as empirical and quantitative data-driven replicability; difficult when the data and concepts of language planning scholarship are contingent, transdisciplinary, and often framed by interest and motivation. These characteristics don't mean LPP can't be empirical and quantitative, but that what count as empirical and quantitative processes requires energetic retheorization related to the function of context, politics, and processes of iterative decision-making in public affairs related to language.

A frequently cited definition is Cooper's: "Language planning refers to deliberate efforts to influence the behavior of others with respect to the acquisition, structure, or functional allocation of their language codes" (1989, p. 45). Other definitions include what people do, think and believe about language: "Language policy can be defined as the combination of official decisions and prevailing public practices related to language education and use" (McGroarty, 1997, p. 1). In other definitions there is no place for the non-deliberate realm: "The match of national language capacity to need" (Brecht \& Walton, 1993, p. 3).

Much early thinking sought to locate LPP close to the conventional policy sciences, aiming to generate a "rational matrix": an ordered sequence of bounded actions governed by an overarching design, itself a data-driven rational response to a pre-established problem. This was prominent in the work of Joan Rubin and Bjorn Jernudd (Jernudd, 1973) who make important contributions to systematizing the field. In their work, together and separately, they connected language planning research to the formulation of alternatives, understanding the essential task as normative intervention by those empowered to decide, but emphasizing that proposed alternative courses of action should be evaluated and contrasted. Both specified orderly and systematic procedures such as the "establishment of goals, selection of means and prediction of outcomes," however they were also sensitive to the role of interests and power. Not all scholars have been willing to concede space to interests and ideologies calling for pure technicism. Tauli (1984), for example, called language planning a failure for not asserting that the planner, as scientist, should prevail over the preferences of language users by insisting that scientific criteria of efficiency, modernity, and instrumentalism should prevail over "nostalgia and sentiment." In keeping with the prevailing intellectual climate of scientific optimism, only a minority of LPP pioneers were skeptical about any limits to technical 
protocols and many imagined banishing subjectivity and interests from consideration. While there are, in fact, orderly and sequenced kinds of LPP whose processes of research knowledge utilization are "rational" and "overt," and which collect data in systematic and publicly demonstrable ways, in reality the ordered "rational matrix" holds true for only a minority of actual LPP.

Some definitions do not limit the effects intended by policy intervention and encompass multiple kinds of collective action: "the organized pursuit of solutions to language problems, typically at the national level" (Fishman, 1973, pp. 23-4) and "authoritative allocation of resources to language" (Fishman, 1994, p. 92). Importantly some definitions (Neustupny, 1978, 1983) have also included even mundane practices of individual language use. The inclusion of an individual's language choices, processes of correction, modification and management of expressive alternatives is a radical move that takes LPP into relationship with consciousness and social psychology, raising issues about the degree of deliberateness required to classify practices as LPP.

Neustupny's useful distinction between approaches to language planning, one describing societies which plan language via policy, the other via cultivation, was further developed to distinguish between correction and management of language issues as the superordinate frame for describing language planning, with subordinate categories of treatment (organized and deliberate attention to language) and planning for those varieties of language treatment which seek to be theoretically structured and highly systematic. In his "correction model" Neustupny speaks of communication "inadequacies" which exist in both the communicative acts of individuals and the communicative system in general. Inadequacies lead to hypercorrection and an increase in the consciousness of the speaker. Problems in the communicative system lead to a meta-linguistic correction system of the teaching and the treatment systems, while individual speakers note discrepancies in the system or forms they are using, find a design for its removal, and decide whether to implement the identified change. Neustupny's approach is interesting for this ambitious attempt to see through, initially by analogy and later by systematic structuring, a connection between individual and societal treatment of the LPP process; although he reserved the term language planning only for those treatments that draw on explicit LPP theory and which are characterized by systematicity and future orientation. An appealing alternative possibility is that LPP can be conceived not simply as the societal and conscious analogue of personal language correction processes, but that the personal and the societal are both instances of LPP located relationally along a single continuum of actions.

Fishman's many contributions have grounded LPP in social context and national setting, and have been especially prominent in examining LPP as intervention in language ecology (maintenance, revival, and shift). In a 1974 work Fishman conjoins in a single framework modernization and development models with LPP. Four language problems are characterized: selection, stability, expansion, and differentiation, each corresponding to LPP processes, respectively: policy-decisions, codification, elaboration, and cultivation. These result in the outcomes identified by Ferguson (1979), another pioneer of LPP theorization, as graphization, standardization, and modernization. This work exemplifies the continuing attempts to devise coherent relationships between societal and linguistic planning processes. Often the societal is identified as the base problem, stimulating the activity in the first place, with the resultant outcome characterized in language terms.

Fishman (2001) has also pioneered new areas of relevance for LPP and tied it to identity in ethnically plural settings, language beliefs and attitudes, religious and sacred experience, as well as to language regeneration efforts of indigenous and immigrant minorities. His Graded Intergenerational Dislocation Scale is an instrument for locating a language on a descending scale as a heuristic for intervention to regenerate and revitalize languages in various states of attrition, facilitating cost benefit analyses of reconstruction efforts. This is an important tool for LPP that combines community effort with expertise, and further ties LPP to the policy sciences. 


\section{The "Activity"}

The term "language planning" became prominent in the work of Haugen (1966) who made it the overarching category encompassing societal intervention in language. Haugen's still popular systematization distinguishes between: selection of form, codification of the selected form, implementation of new norms, and their elaboration into various public domains, including institutional and cultural cultivation of language.

Kloss (1969) divided language planning into two branches of activity: corpus and status planning. Corpus planning refers to norm selection and codification and is usually undertaken by language experts, resulting in dictionaries, grammars, literacy manuals, and pronunciation and writing style guides. Status planning is rarely entrusted to language experts. The results of status planning are laws, clauses in constitutions prescribing the official standing of languages, and regulations for their use in public administration. This institutional and administrative focus is generally for nationsolidifying purposes and aims to secure a language, or its preferred orthography, over national territory or, in cases of imperial or economic expansion, to spread beyond it. Corpus planning is often undertaken to overcome communicative inefficiencies, usually driven by ideological imperative. Typically these ideologies have been nationalist postcolonial reconstruction, but social movements also advance political aims through modifications to the lexis and discourse patterns of language. Examples in English have been university campus speech codes promulgated in the interests of antiracism and counter-sexism, indeed for most kinds of linguistic political correctness. Pursuing social change via linguistic reform is based on a sense that social power and representation correlate with language or are consonant with more performatively based understandings of language (Butler, 1997) that consider language constitutive of social identities and politics a lingually performed practice. Status and corpus planning are the major activities discussed in LPP literature, but three other activities are studied.

Acquisition planning (language-in-education) typically describes the languages teaching policies of states. Foreign or second language instruction can be motivated by humanistic rationales, by economic interest calculations, by assessments about national security or geo-political interest, or by responses to the needs, opportunities, and rights of linguistic minorities.

Usage planning refers to efforts to extend the communicative domains of a given language. This usually occurs in opposition to a replacing language after political reconstitution (administrative devolution, federalism, or national independence) but in more extreme cases usage planning forms part of regeneration efforts on behalf of dying languages.

Prestige planning involves elevating the esteem of a linguistic code. While this often accompanies status planning, there is an ancient history of poetic, philosophical, and religious involvement in attaching enhanced prestige to given codes that precedes formal planning processes and sometimes contradicts them. The production of canonical literature by poets, prose writers, and other cultural figures has effects that can be usefully discussed as language planning.

These five language planning actions are rarely separate. In practice they overlap and are mutually producing. Their goals are to alter or entrench the status, extend or modify the corpus, enhance or deepen the acquisition, disperse the usage and elevate the prestige of linguistic codes. I believe that we need to include an additional, critically oriented, activity: discourse planning.

Discourse planning refers to the influence and effect on people's mental states, behaviors and belief systems through the linguistically mediated ideological workings of institutions, disciplines, and diverse social formations. Although discourse is quintessentially dialogical, and by definition permits 
contest and negotiation, planning discourse refers to the efforts of institutions and diverse interests to shape, direct, and influence discursive practices and patterns. Often discourse planning seeks to represent as natural ways to think that are socially constructed, and therefore contestable, interested, and motivated, by influencing the predisposition of people to think in particular kinds of ways. At its extreme discourse planning approaches Orwellian thought control, more commonly it specifies the motivated, though not necessarily deliberate or conscious, use of speech acts to effect influence and persuasion. Some discourse planning is reflexive, aiming to influence how people think, behave, and value language itself. As such, discourse planning is the ideological accompaniment of other kinds of LPP practice, such as the persuasive discourses of public authorities engaged in status planning.

\section{Modernization, Authenticity, Development, and Theory}

For much of its contemporary history LPP theory focused on the particular needs of developing nations (Eastman, 1983) and on processes of modernization. A seminal text (Rubin \& Jernudd, 1971) was subtitled "Sociolinguistic Theory and Practice for Developing Nations." The standpoint suggests a little problematized notion of a "linguistically settled" end-point nation, suggesting an archetypal national order synonymous with western modernity, imagined as either uni-lingual, with uncontested orthographic conventions, in which the population is maximally literate, or at least not problematically plurilingual. This modernization involved progressive specialization in economic domains, lessening of clan, tribal, and ethnic bonds, and their substitution with the identities and relationships of liberal, industrial, and post-industrial consumerism in which standardized, codified national languages and near-universal literacy, predominate. The "normality" of the state modeled from Europeanized monolingual polities often collided with local realities and experiences of the relations between identity, polity, and communication (Mansour, 1993).

By foregrounding multilingualism as a problem, the logic of LPP had often been to place communication practices into hierarchically organized classifications, via differential status allocations, differential literacy elaborations, and different ideological associations. More persistent were assumptions that extensive multilingualism necessarily correlates with poverty and underdevelopment. Pattanayak (1987) shows that a range of modern scholars has discussed multilingualism negatively, as causing backwardness and economic underdevelopment. The following maxim-like point exemplifies this: "a country that is linguistically highly heterogeneous is always undeveloped, and a country that is developed always has considerable language uniformity" (Pool, 1972, p. 213).

Fasold states: "It is obvious that multilingual states have problems that more nearly monolingual ones do not ... difficulties in communication within a country can act as an impediment to commerce and industry and be socially disruptive" (1984, p. 4) and "there is a definite relationship between linguistic uniformity and economic development" (p. 7). Although he does indicate some benefits of multilingualism, he argues that linguistic "diversity is inversely related to development." Fasold concedes that such a relationship may not be causal, resulting from arbitrary postcolonial boundary setting (p. 134).

The modernization-developmental connection has lessened considerably in LPP writing, partly through increased prominence of Asian and African theorists positing new kinds of polity and asserting naturalness for linguistic pluralism, partly through exposure of the westernizing assumptions these connections carried, but also through new multilingual challenges becoming prominent in Europe and in the "new world" Europeanized states. Very rapid economic growth in China and parts of South India, based on high-tech innovation, will likely cause further modification to assumptions whose essential error has been to confound societal multilingualism with an absence of interlingual communication, an especially problematical assumption for sociolinguistics which foregrounds the 
idea of overlapping discourse communities and the functional specialization of speech and communication domains.

More broadly, patterns of economic modernization, especially in north Asia, have not necessarily reproduced the model of the developed nation typical of European economic modernization, challenging parts of the paradigm of classical LPP. Romanized writing is not inevitable for modernization (Gottlieb \& Chen, 2001), new technological innovation allows voice instruction and renders less necessary any kind of alphabetization and even disrupts classical speech-writing hierarchies, but the modernization-language-development connection remains a crucial topic in LPP, especially prominently in light of global English (Lo Bianco, 2002).

\section{Language Planning in History: No Unitary Purpose}

LPP is as ancient as language itself, is expanding everywhere, and is used for many different purposes. Some early theorization (Eastman, 1983, p. 126) imagined a unitary disciplinary purpose: "a field that seeks to foster ethnic interaction, world communication, and national identity," but the vast diversity of its historical and actual practice belies such a possibility, and although it is theoretically possible that academic training in LPP could produce a unified ethics of practice, the field of language planning is not guided by common goals. Language planning serves multiple and conflicting interests. The subjectivity of planners is central for an account of LPP) that seeks to comprehensively deal with its practices.

In the third century BC India's only Buddhist Emperor, Ashoka, pursued political unification via linguistic toleration while Qin Shihuangdi, first emperor of a united China, suppressed regional scripts (an opposite policy for a similar objective), selecting a single standardized writing variety (the Small Seal) and mandating its use (Ferguson, 1979/96). These ancient precedents have modern manifestations; India's constitution continuing Ashoka's pluralism and in China's unitary policy.

At a similar time in the west language planning exhibited language and world-view beliefs. Plato advocated free literacy to counter communal poetic recitation aiming to "break the power base of Homer and traditional culture" (Gee, 1996, pp. 32-5), believing that through dialogic language Athenians might be "disenchanted" from the blandishments of Homeric verse and its dangerous "magic" that made the citizenry pliable and unthinking.

The European language academies (Florence, 1582; France, 1635; Spain, 1713) aimed to cultivate prestigious literary culture, but also laid the basis for subsequent national politics. Cultivated literary languages merged with the idea of national culture, advocacy for unique and bounded states to reflect language borders followed (Hobsbawm, 1993), under industrialization, with standardized mass literacy in national languages. This long evolution of canonical literary forms, eloquence and scientific discourse, and mass basic literacy, supports Coulmas' $(1989,1994)$ argument that languages do not yield standard forms naturally (these are cultural achievements), and Joseph's (1987) analysis of "eloquence" and its power as culturally specific, and variable. Linguistic evidence for nationalist politics spawned new nations and revived old ones. The invention of the linguistic minority (Heller, 1999), the creation of border communities, the emergence of polycentric, national-variety, languages, and other fall-out from determining political space through notions of language and culture as much as through power and force, spawned an expansion of deliberate language engineering, cultivation, and propagation that continues unabated in Europe, as elsewhere, today.

The nation-language ideology served Apartheid's originators to legitimate forced relocation of African peoples. In processes not always self-conscious or deliberate, scholarship joined policy. Uninterrupted speech chains were ruptured, inventing languages just as interpretable as mutually 
intelligible varieties, devising different orthographic conventions, and attaching the results to a discourse of uni-lingual nation-entities; all constituting evidence of separateness necessitating divided geo-political space (Alexander, 1989, p. 22). Linguistic classification and "scientific" nomenclature can be saturated with politics. This served Apartheid's project of "breaking up the black people into a large number of conflicting and competing so called ethnic groups" (Alexander, 1989, p. 21). Since 1996 language planning serves a dramatically different meta-policy in a South Africa seeking to forge a trans-ethnic but multilingual state but which pits progressive constitutionalism against the marketdriven power of English in a post-national globalization (Webb, 2002). Several centuries earlier, LPP produced in Sweden the world's highest literacy rates (far higher for women than in many countries today), an outcome motivated not by any literacy motivation but by commitment about direct, unmediated, encounter with God's word (Gee, 1996). In the eighteenth and nineteenth centuries the world's biological and chemical terminologies were rationalized by Linnaeus and Berzelius (Dahlstedt, 1976). From such experiences the Swedish Academy has evolved a function independent of state, issuing rulings on terminology, pronunciation, and spelling that are accepted in popular and technical domains. This expert-driven and authoritative rationality is sustained by a "total Swedish societal ideology" (Dahlstedt, 1976). Altogether different is the "creation" of Modern Turkish, replacing its Ottoman predecessor, a process preceded by romanization, and combining cultural innovation, modernization, democratization, imposition, cultivation, and ongoing contest resulting in what, according to Lewis (1999), has been a "catastrophic success."

More like Turkey than Sweden, but particular as well, is Vietnam's evolution of its writing system (DeFrancis, 1977; Lo Bianco, 2001a), the only nation to romanize Chinese orthography. This "policy" is the fruit of millennial struggle against various colonialisms, with multiple language and writing alternatives at different times, shifting reactions of the mandarin scholar-gentry class, colonial administrators, revolutionary and conservative politicians, poets and writers, and peasantry to the language options imposed or favored by various dominating outsiders and internal collaborators.

Accounting for any of these experiences of LPP could never be adequate from a disciplinary source grounded in language study alone, much less from linguistics, however conceived, but needs to be informed by historical, political, educational, and economic scholarship. However, since history, economics, education, and political theorizing invariably neglect to account for the role of language over time, in resources, in instruction, and in relations of power, a distinctive transdisciplinary applied discipline, grounded in real-world data, is required, otherwise language policy histories are rendered subservient to broader analysis that cannot account for its specificities. Located between human sciences that pay scant attention to language, and linguistic accounts that pay scant attention to context, a transdisciplinary language planning theorization is essential. Its reach and methods must far exceed the limits both of descriptive accounts of language and of the invisibility of language to historians, economists, and political scientists. An account of the Vietnamese case needs analysis of the peculiar "micro-linguistics" of graphization, a tri-graphic hierarchy of three scripts: Chu Han (Chinese writing of Chinese), Chu Nam (indigenous adaptation of Chinese writing for Vietnamese), and Quoc Ngu (romanization of Vietnamese), along with romanized French, alongside analysis of the languages this tri-graphia favored or impeded (Chinese, Vietnamese-influenced Chinese, French and Vietnamese). And all this must be grounded in the real-world contexts of the social, political, cultural, and economic interests that were advanced or retarded, the development, modernization, revolution, mass or elite literacy that the tri-graphic hierarchy made possible or difficult. These language-specific inflections of history, economy, education, and revolutionary or reactionary politics can never be accounted for fully within a solely contextual analysis and yet will always be inadequately accounted for without reference to the enveloping context (Lo Bianco, 2001a).

Some dimensions of language policy-making, beyond direct language activism, are dispersed among communities and reside in the ordinary practices of language use, confirming and disconfirming promulgated norms, invoking and resisting identities, advancing or retarding ideologies. Language 
practices, inherited as tradition, and language itself, populated with the meanings, associations, and ideologies of past speakers and present usage, constitute what speakers inherit, the past "policy" of the language resource of a collectivity, and these enter into complex relation with assertive institutions and authorities. This account is influenced by ideas on language as voice and dialogue, from Voloshinov and Bakhtin (Dentith, 1995), and is crucial to the present claim that LPP needs revitalization with the inclusion of discourse planning as a legitimate field of LPP.

\section{Critiques}

Academic marginality has not shielded language planning from attack. Perhaps severest has been the allegation that LPP is complicit with social repression in the interests of state and class (Luke, McHoul, \& Mey, 1990). Mühlhäusler (1995) holds that when applied by developed-country experts (operating with notions of "one national language") to intergenerationally stable multilingual nations in post-colonizing contexts LPP can lead to the creation of hierarchical diglossia among existing languages and varieties, and in turn this can lead to erosion and the ultimate demise of minority languages. Relatedly, the spread of anglophone westernizing modernity can lead to the destruction of distinctive life-worlds and the depletion of the alternative worldviews that reside in diverse linguistic systems (Nettle \& Romaine, 2000; Phillipson \& Skutnabb-Kangas, 1996; Skutnabb-Kangas, 1995), the result of the absorption of poor and marginalized peoples into global consumerism.

Another allegation has been that LPP has entrenched economic inequalities for immigrants in first world societies by language educational schemes tracking immigrants into low-paid, marginal jobs (Tollefson, 1991). The methods of LPP have been criticized for depending on positivistic, rationalist epistemology (a "pretence to science") and for relying exclusively on technicist-scientistic techniques (Luke, McHoul, \& Mey, 1990). For Moore (1996) LPP theorists adopt an uncritical stance toward their own practices and operate with excessively descriptive approaches. Moore uses Dorothy Smith's sociology, which implicates scholarly practices in "relations of ruling," naming others' lives and experiences, inscribing outsider appropriations into orders of action that impose "invented" categories on lived experience; scholarly "overwriting" as domination.

The archetypal methods of LPP such as the sociolinguistic survey, and the rational choice matrix, the latter an analogue of management formalism:

(1) Identification of Problem (fact-finding); (2) Specification of Goals (development of policy); (3) CostBenefit Analysis (weighing up alternatives with rational demonstration of the ultimately preferred one) (4) Implementation (5) Evaluation (comparing predicted to actual outcomes), are criticized for "masquerading" as neutral information-collecting instruments and ordered action-sequences. Critical scholarship argues that these methods can produce the means for bureaucratic and technocratic management of the lives of minority communities. Outsider, scholarly, ways to know and represent can predominate over insider lived experience, and serve the interests of state agencies, corporations, statistical documentation practices, and even proselytizing religious orders (Sommer, 1991). Such criticisms allege that formal processes of analysis in the service of commissioning agencies manufacture "factive" representations over communities otherwise independent of centralizing and hegemonical apparatuses. Such representations are often framed as information required to "solve" social, educational, health, and occupational problems, invariably seeking to alleviate "disadvantage."

Fishman rejects the most extreme of these criticisms (1994) but calls on LPP scholars to adopt stances, conceding that LPP cannot reside in some ideology-free zone being used by "ethnicisers, nativisers and traditionalisers" who "engage in language planning for their own purposes" (Fishman, 1994, p. 96). 


\section{Problems}

A distinctive dimension of LPP theorization has been its struggle with "problems." Much LPP theory adheres to a view that LPP scholarship starts with a response to predetermined language problems. Some scholars have attempted comprehensive characterizations of language problems, most impressively Dua $(1985,1986)$, who claims that the "systematic account of language problems of a speech community is a prerequisite to an adequate theory of policy formulation, language planning and language treatment" (p. 3). Dua's scheme specifies various categories of people who define problems, insiders/outsiders, politicians/bureaucrats, researchers/professionals, and "the people," and specifies four social needs that defined language problems reflect:

Normative needs: definitions in which professionals or experts dominate;

Felt needs: definitions in which affected groups or individuals prevail in the process of defining;

Expressed needs: those felt needs that are converted into action; and,

Comparative needs: establishing a contrast among needs such as temporal, situational or locational.

Dua's matrix further complicates according to how needs are handled, involving a series of oppositions, broadly/narrowly, deeply/superficially, precisely/vaguely, and rationally/irrationally. This desire to comprehensively characterize is also exemplified in Nahir (1984) who identifies eleven intended treatments for language problems: purification, revival, reform, standardization, spread, lexical modernization, terminology unification, stylistic simplification, interlingual communication, language maintenance, and auxiliary-code standardization.

Attempting to characterize the totality of language problems in taxonomies underscores the vast complexity of LPP. However, and quite problematically, which language problems are allocated policy treatment is embedded in conflict about interests, probably only identifiable from critical perspectives. LPP sometimes appears to take claims by public authorities about policy intentions at face value, failing to recognize what the scholars would, as citizens, ordinarily recognize, that political language is inflated, and that LPP is framed by political discourse. How many times does it occur that in electoral debating concessions are made to certain publically demanded principles only to be denied in practice, witness the legendary status of the political promise. LPP is also politics.

Most LPP scholarship has not been naive about the problematic nature of problems; there has been insufficient attention to the ideological character of processes for the determination of which language problems are allocated policy attention. LPP has wanted to describe processes of status, corpus, prestige, and usage planning without adequate regard to the prior structuring processes of ideology, discursive politics, the contest about what representations of language, what language problems, will be constituted for state agency or authoritative intervention. In public policy literature, however, there has long been an acute sense of the politicized character of policy problems with Edelman (1988) arguing they are ideological constructions that "come into discourse and into existence as reinforcements of ideologies" (p. 12).

An exemplary instance of this is the politics that surround the official English movement in the United States. The moves legislate English as "official" is, at face value, a classic instance of status planning, but what is the problem that these expensive and extensive (and materially redundant?) efforts respond to? Is it "Hispanophobia" (Crawford, 1995), "war against diversity" (Crawford, 2000), a moralistic "Reagan renaissance" (Tarver, 1989), "civilization" for the "American underclass" (Gingrich, 1995), rolling back expensive leftish "official multilingualism," or the "need" to "protect English" (Lo Bianco, 2001b)? 
Most dramatically, is American democracy, founded on English libertarian principles, at risk and needing its House of Representatives and Senate to make a stark and historic choice between "Democracy or Babel!" (de la Pena, 1991)?

The language problem that precedes and shapes language policy and planning is no straightforward thing, immersed as it is in discursive politics.

\section{Praxis as (Past) Planning}

Planning is itself a problematical notion, since it suggests changing the future. Is what we ordinarily do, with language as with most other behavior, past planning in action? Is the "default" system with which we mostly operate in mundane life simply the operation of what was previously consciously determined, and is now praxis? In a longitudinal study of US bilingual teachers, Shannon (1999) comments on what happens when there is an absence of explicit policy formulations, apart from broad policy, and finds that "practice" becomes "policy." In the absence of overt or explicit detailed planning, teachers make recourse, through underlying beliefs and values, to patterns of behavior that reflect past accommodations or past policies, sometimes contradicting the broad policy altogether. Thus ideology operates as "default" policy.

Recent approaches to the study of attitudes, values, and beliefs as constituting an ongoing, daily politics of language ideology (Schieffelin, Woolard, \& Kroskrity, 1998) sustain Shannon's approach. Bakhtin's conception of ideologically laden discourse, most evident in "authoritative" contexts, where discourse: "is indissolubly fused with its authority - with political power, an institution, a person..." (Bakhtin, 1981, p. 343) extends this thinking, suggesting that what is default is in fact powerfully shaped by authoritative extant discursive representations, institutionality in discursive practice, and praxis, what is routinely done, as its daily enactment or performance.

The language ideology connection can be demonstrated by different constructions of what twolanguage teaching in schools "means." Two-language education is found in all parts of the world, but it is rarely the same thing, sometimes being marked as progressive, interesting, or enriching, other times as oppressive and regressive. Australian bilingual education can be simple acknowledgment of minority children's educational potential (Djite, 1994), or a conspiracy by a self-serving "educational establishment" denying indigenous children English literacy (Lo Bianco, 1999). Canadian bilingual education can be a politicized concession to Quebec nationalism, but also educational and social enrichment (Heller, 1999). US bilingual education can be anti-poverty measures for disadvantaged Mexican-American pupils (Schneider, 1976), or education that "integrates language minority and language majority students in the same classroom with the goal of academic excellence and bilingual proficiency for both" (Christian et al., 1997). Most extreme, the language policy aimed at teaching arithmetic and social studies in Afrikaans alongside English became "the immediate cause of the 1976 Soweto uprising" that resulted in the deaths of many students (Juckes, 1995). Two-language education, like any LPP measure, assumes specific political meaning which at the conjunction of overarching ideologies and specific histories, in real-world settings of conflict, opportunity, resources, and relations among groups.

Discourse, in its naming and framing problems, contributes in forming epistemological bases for understanding the world and is constitutive of perception. A reinvigorated theorization of LPP requires the addition of discourse planning to adequately explain, even to discuss, policy action in which language is the object of attention, obviously most in those domains where there is contest, conflict, and dispute. The key aim is to account for the language of politics in language planning theory, how language problems are construed discursively for policy attention, a process that results in selective elevation of some language issues to policy attention, while silencing alternative claims. The inclusion 
of the political discursive realm within the remit of LPP seeks to understand the constitution of language problems as a performative practice, engaging both traditional notions of rhetoric and persuasive talk, but also the actual accomplishment of goals of language policy through ideological structuring.

Language is a deeply problematic object of the conscious processes of planning because it is also the medium for its constitution as an object for policy attention. Policy and planning are interventions into "natural" ecologies, disrupting processes of evolution, diversification, and standardization. The most general purpose of intervention is to assert deliberative control. The imposition of deliberative, consciously-intended ends onto semiotic practices that have ecological character as substantive fields with endogenous developmental processes and histories raises questions about control exercisable by intervention and the ambiguous effects of intervention. It also foregrounds the connection between personal language practices and the societal domain. The official English movement in the United States is salient because of the material absence of what classical language planning would constitute as a "language problem," or, better, the heavily ideologized character of the "language problems" advanced for policy treatment. Making central within LPP the analysis of policy discourses surrounding the constitution of language policy problems establishes the performative character of the disputation around the status of English in America. Some discourses demand acknowledgment of English as "the language of America," America understood as a political community, united by claims to a tradition of liberal individualism and enterprise. These claims are an indispensable part of policymaking, the state-talk that policy talk is seeking to enact, but the discourse seeks not only to stimulate legislative action, it is itself policy action, performance of an extended routine of naturalizing associations of English with national iconography and values.

Praxis, and discourse, here constitute and perform, through countless reiteration, over time and space, illocutions (speech acts whose effects are immediate if persuasive) and make available public perlocutions (effects dependent on the material responses of lawmaking).

\section{Sciences of Language}

Underlying the possibility of any kind of language planning is the notion that "language ... is ... subjected to human action and control ... This insight is the basis for all language planning" (Bartsch, 1988, p. 147). This insight tells us that language is not static and uniform, but not what it actually is. Different sciences of language investigation have struggled to more or less strongly locate the linguistic sign in relation to context, system, inter-subjective iteration, and the material world.

Newmeyer (1986) contrasts "autonomous" linguistics with three conceptions of language that connect it to external non-language realities: sociolinguistics, Marxist-oriented linguistics, and "humanistic" aesthetics. He takes "autonomous" approaches to mean generative linguistics, alongside its structuralist forerunners deriving from Saussure. Newmeyer's search for a characterization of language and context aims to look past what he characterizes as linguistic "modernism," a goal shared by Pratt (1987) who claims that underlying the formalizations of autonomous linguistics are "utopias," idealized assumptions about community and shared identity. Both identify an oscillation in approaches to language description between greater and lesser contextualization, like Hanks (1996), who substitutes "communication practices" for "language" as the center of scholarly interest. This oscillation is inflected in each historical phase in the research questions that occupy expert scholars of language. The inflections mean that similarly underlying questions recur in specific, grounded instances in new times under the rubrics of linguistics and applied linguistics. Although this process reflects a wider intellectual history of alternating periods of universality and relativism, the pattern of oscillation within language theorization is influenced to a considerable degree by practical constraints that faced scholarship, with spoken, and "fleeting," language now more amenable to systematic study, 
freed as scholars are from the constraints that Voloshinov called the "cadavers" of abstract systems, the dead texts that animated the interests of philology (in Dentith, 1995).

Other kinds of linguistics offer alternative ways of "seeing" language, and ground discussion of grammar, correctness and norms, in theories that give rise to different dilemmas concerning normative knowledge. These dilemmas suggest particular connections between informing language theory and practices of language planning. If applied linguistics isn't linguistics applied, or isn't just linguistics applied, we still need to ask what is the linguistics that isn't or is only partially, or only occasionally, applied? Three different sciences of language producing different kinds of LPP are considered.

A view of socially-made meaning, social semiotics, is central in the Systemic Functional Linguistics of M. A. K. Halliday and yields theorizations of the practice of policy and planning intervention different from those that claim descent from descriptive linguistics. Specifically, in Halliday (1993), a different base notion of language generates an approach to LPP which sees the "meaning resources" of a community, its children in school, or its science, social relations, and politics as expandable, or restrictable, on the basis of explicit connections between structure and semiosis, deriving from his explicitly made interconnections between language and the material realm. Halliday distinguishes between institutional and systemic LPP. The latter is more innovative and follows from sema-history notions, that is, stages of history and the relations between language and materialism, class, sex, and race. The relation between evolution and intervention refers to limits posed by grammar's base, the relation between social structure and language in different phases of history, as well as its disjunctions. Hallidayan inspired LPP would differ from conventional theorizations in several ways because semantics, not form, would be the central issue for investigation. In contemporary LPP theory acquisition planning refers to the efforts states make to teach foreign or minority languages, occasionally to the adult literacy campaigns in postcolonial nations. Notions such as "expanding the meaning resources of learners" would count as the central practice of a Halliday influenced LPP, whereas much post-war LPP has neglected national literacy education. Although sometimes "intellectualization" is cited in conventional LPP as code-centered corpus planning in Hallidayan inspired LPP, this process of extending meaning potential would be the central issue of examination and not a marginal one.

The second language science that would produce a radically original LPP is located in the "identity" orientation that shapes the linguistics of Le Page and Tabouret-Keller. Le Page and Tabouret-Keller $(1985)$ and Le Page $(1988,1993)$ propound a unique view of language as science, and of the sorts of intervention that create what they regard as "language." A key premise of their theorization is a highly dynamic inseparability of language, "a repertoire of socially marked systems" (Le Page \& TabouretKeller, 1985, p. 116), from the practices and instances of its use, questioning the ontological status of many of the categories assumed by conventional linguistics and challenging the fixity of these categories (ethnic groups, languages, dialects, different languages). This challenge derives from the locus of language; which they find residing in individuals whose creative and massive variations in its use reflect constant negotiation and change. Every speech act involves the projection of the "inner universe" of the speaker "implicitly with the invitation to others to share it" (Le Page \& Tabouret-Keller, 1985 , p. 181). This projection produces adjustments ("focusing") based on the feedback from the interlocutor's response to the language projected, in some measure reinforcing the original or producing its modification as the original speaker accommodates to the feedback received. Projection involves a creative and constitutive set of operations whereas focusing involves progression from simple feedback to incorporation and institutionalization.

Individuals inhabit and create a "multidimensional symbolic universe" (Le Page, 1988, p. 32) surrounding them with a multitude of possible linguistic choices and selections based on the interplay of projection and focusing. Le Page distinguishes between standards as norms and as prescription. 
The former comes about through focusing, the dialogical process of fit between projection and feedback, and is largely unconscious. This process can account for language change and development and even for rigidities in some processes (monastic scriptoria). Prescriptive norms on the other hand derive from the awareness of stereotypes based on norms. Le Page argues for example that Received Pronunciation originated in the "close interaction" between public schools, Oxford and Cambridge, and the "Mandarin ranks of the civil service" in the latter part of the nineteenth century and early part of the twentieth. Projection and focusing are understandable as LPP processes that make dynamic reformations of language commonplace, but also help to explain stable phenomena.

A third alternative LPP can be constructed from critical approaches to language. Critical linguistics is premised on the idea that language and ideological systems are inseparable, but that these connections are naturalized, made to seem like common sense, and therefore masquerade as normal when in fact they represent and carry interest. Fairclough $(1989,1995)$ argues that language is the prime locus of ideology, that this insight of critical and social theory (influenced by Bourdieu, Foucault, and Habermas) is evidenced by the "linguistic turn" in contemporary social theory and is critical precisely because it reveals connections of power and ideology with language that are otherwise concealed through "linguistics proper." For critical linguistics, a theory of social practice that does not reduce or overly elevate individual agency and creativity, nor the determinative power of convention or structure, is the defining parameter of the field.

This approach rejects the classic base of descriptive (or autonomous) linguistics, in the tradition of Saussure, as unacceptably a-social, overly formalistic, with the related stress on synchronic analysis and abstract characterizations. Furthermore, critical scholarship argues that conventional sociolinguistics only seeks correlative relations between social structures and aspects of language (running the risk of legitimizing such correlated forms by a-critically describing their contextual "appropriateness," when critical linguistics might seek to problematize such relationships). In this vein Gee (1996, p. 104) states that "Since language situates speakers and hearers within fields of status and solidarity, and since these are inherent social goods to humans, all language is always and everywhere ideological."

Political linguistics is a term that has arisen within LPP writings, especially among critically inclined scholars. In settings where language correlates with major economic inequality Calvet (1998) takes a strong approach: "All planning presupposes a policy, the policy of those in power ...by intervening in languages, he becomes part of the power game" (Calvet, 1998, p. 203). For in vitro experimentation to succeed it must work in vivo and Calvet's view is that the actual position of the linguist is predictable,

usually the linguist is to be found on ... the side of power, even if he only considers himself as a technician or adviser... language officials ... risk becoming servants of the state ... intervention by planning tends to dispossess speakers of their own language: all planning is carried out by a handful of planners possessing all the power over a people who are planned. (p. 203)

His one way out seems to derive not at all from professional ethics or responsibility but from citizenship, since "language policy is a civil war of languages..." so a linguist must "behave as a citizen and keep democratic watch..." (1998, p. 203). This position precludes a place for a kind of systematic scholarship that may be aware of the interested and motivated nature of policy and planning but which may still be systematic, careful, and scholarly; and may even work counter to dominant forces.

For Blommaert the challenge for LPP is positionality: 
Taking sides is unavoidable: it comes with doing a particular type of questioning of linguistic reality. An attempt at providing a history of language, which takes into account social and political factors, forces us to voice interpretations of these factors. And in social and political reality, interpretations are partisan, and they almost automatically align the one who formulated the interpretation with one or another political bloc. So be it. (Blommaert, 1999, p. 437)

For Blommaert and Bulcaen (1997) this constitutes what they call "political linguistics."

New intellectual forming sources for a reinvigorated LPP also come from critical sociology, such as the work of Bourdieu $(1982,1991)$ and his analysis of a kind of human subject that makes central the ideology of economy. Bourdieu has produced an analogue of the economic human within a symbolic market. In Bourdieu's scheme there are four kinds of capital available to interacting humans: Economic Capital (various kinds of material wealth and assets), Cultural Capital (knowledge, skill and education), Symbolic Capital (accumulated prestige or honor), and Social Capital (connections and group membership). Individuals are distributed according to the configurations and quanta of capital that they possess and how the capital stocks can be transformed in social life into advantage. Power is taken to be the capacity of individuals to mobilize the authority accumulated in a market by deploying their capital stocks. This kind of power is a symbolic transmutation of coercive force.

For Bourdieu "buying and selling" economies are located within a communication economy in which linguistic interchange is a critical social practice. His is both a metaphorical rendering of marketplace terms and practices of language and a real analysis of the actual interplay of communicative exchange. Within these communication economies symbolic domination is effected by asymmetrical capital endowments. These take the form of a habitus in which the social person operates not just at linguistic dimensions but also with consequences in material capital. Bourdieu's analysis of the historical unification of the French linguistic market from pre-revolutionary to Republican times shows the operation of symbolic domination processes so that state linguistic unification and formal officialization accompanied each other.

The constitutional enshrinement of French was bolstered and made possible by the officialization of Parisian in the symbolic marketplace. It was not just that the state required standardized forms of literate language to operate its technical mechanisms of nationing and administration, but that there was a "'struggle for symbolic power in which what was at stake was the formation and re-formation of mental structures" (Bourdieu, 1991, p. 48). The legitimization and realization of the language of stale, with its content shifts toward new terms of address enshrining new social relationships, new metaphors and euphemisms, was a political struggle for the kind of language that a new social order demanded. This centralizing, hierarchical and universalizing, involved marginalizing local differences in the interests of Republican citizenship. This approach to LPP reveals a clear connection between micro-linguistic performativity of the macro-sociopolitical change of authority for French.

Bourdieu points out that symbolic domination utilizes and indeed ends up being a practice of euphemization; in effect a kind of self-censoring, governmentality in Foucault's language. The market results in euphemization because of a process of anticipation (Thompson, 1991). Adapting to the preeminence of certain kinds of dominant linguistic capital creates a hegemonizing of the extant power relations. It gives effect at the interpersonal linguistic exchange to a wider societal project of language officialization. Persuasive powers are "obeyed" in anticipation of their deployment.

Foucault's conception of how chainings of meaning are discursively related and repress alternative formations, and how these are historically produced though loosely structured combinations of statements, is relevant here as a kind of "discourse planning." In policy work this occurs through 
specialized and powerful kinds of knowledge that policy science generates, knowledge designed for action; knowledge whose techniques of production stress precision and validity, and claim to remove ideology and interest. For Foucault "There is no power relation without the correlative constitution of a field of knowledge, nor any knowledge that does not presuppose and constitute at the same time, power relations" $(1979$, p. 27). These insights are relevant to a reconceptualized LPP in that they assist us to explain not only instances of language planning but also how the discipline itself arose and what particular interests it has.

\section{Discourse Planning}

In an attempt at a comprehensive post-World War II intellectual history of LPP, Ricento (2000) identifies three phases characterized by research questions, methodologies, and goals. Early work was predominantly technicist and technocratic with expert specialists promulgating solutions for newly emerging postcolonial states utilizing a "developing country approach," but with little problematization of methodology, "developed country" assumptions, or interests. The second phase is characterized as a kind of neo-colonial re-think after the failure of economic "take-off." The current phase is shaped by a realization that LPP is not "philosophically neutral" leading to a challenge to its base in autonomous linguistics and some of its cherished ideas: native speakers, mother tongues, diglossia, national languages, bounded literacy, languages as discrete and bounded entities (instead of "will to community"), finite grammars, among others. Ricento claims that LPP today shows alarm about linguistic imperialism, language extinction and sees language and literacy as plural, contingent, and hybridizing social practices. The Ricento approach is helpful in bringing together contextual factors, intra-discipline epistemological change, and periodization. Inevitably such schemas can only be suggestive since time boundaries are never absolute, and the third stage is less new theory and more position taking.

What is proposed here is the addition of a category of language planning analysis, discourse planning, which understands discourse as both shaped and performing. The spirit of the informing linguistics identified above, and the limitations of descriptive analysis, partially motivate this proposal. The examination of persuasion and politics in language is not new, what is called for is the inclusion within LPP of the discursive realm as the key domain for the performance of language planning praxis. When persuasion and politics become focused on language itself, LPP becomes reflexive, and cyclical, the language of persuasion becomes deployed in the interests of enacting policy on language as object. Language here is both the means and object of itself. By scrutinizing the language of policy-making, using insights and methods of ethno-methodology to undertake micro-examinations of how language issues are constituted as problems for treatment by policy, we can integrate, if not reconcile, approaches to the study of language policy which are both systematic and empirical with approaches that acknowledge the ideological character of discourse. The examination of policy discourses, especially how policy discourses constitute problems for policy treatment, is a neglected field that will extend the scholarly range and rigor of LPP.

Language or code focused linguistics makes a choice to reify language and subject it to analysis within the formal conceptual apparatus of autonomous linguistic science. Applied linguistics, on the other hand, tackles contexts in which language issues, or problems, are paramount and subjects these problems to analyses, both empirical and speculative in design, to reach coherent accounts and understandings. Applied linguistics therefore reifies particular social moments, those in which language issues are prominent, and which require active kinds of analysis, aiming beyond understanding, or even explanation, toward scholarly legitimizations of particular courses of public action. Language policy and planning is an exemplary kind of scholarship for action.

Language planning is normative action for intervention (change or anti-change), whose analysis 
requires a reinvigorated intellectual framework combining professional identity formation which and informational practices, among interacting subjects. Critical and political linguistics offer useful conceptual information, as do the alternative linguistic sciences that identify coherent connections with identity as multiple, shifting (but also stable and persisting) and with the material and cultural context. These links (to culture, identity, and material realms) are enacted in verbalization and writing. Other fields of dialogue for the reinvigoration of LPP include the (political) subjectivity of language planners, systematic data collection and careful analysis methods that can operate within realistic incorporation of persisting ideologies, and interest in policy-making. Language policy and planning are ancient, extensive, and predictably expanding. Their understanding and explanation will be enhanced if in addition to more rigorous understandings of status attribution politics, corpus modification processes, esteem and prestige alteration, and impacts on usage, we include analysis of their discursive mediation and construction.

\section{References}

Alexander, N. (1989) Language policy and national unity in South Africa/Azania. Cape Town: Buchu Books, Creda Press.

Annamalai, E., Jernudd, B. H., \& Rubin, J. (eds.) (1986) Language planning; proceedings of an institute. Mysore: Central Institute of Indian Languages; Hawai'i: Institute of Culture and Communications, East-West Center.

Bakhtin, M. (1981) The dialogic imagination. Austin: University of Texas Press.

Bartsch, R. (1988) The norms of language. London: Longman.

Blommaert, J. (ed.) (1999) Language ideological debates. Berlin: Mouton de Gruyter.

Blommaert, J. \& Bulcaen, C. (eds.) (1997) Political linguistics (Belgian Journal of Linguistics, 11). Amsterdam: John Benjamins.

Bourdieu, P. (1982) The economics of linguistic exchanges. Social Science Information, 16, 645-68.

Bourdieu, P. (1991) Language and symbolic power. Cambridge, MA: Harvard University Press.

Brecht, R. D. \& Walton, A. R. (1993) National strategic planning in the less commonly taught languages. Washington, DC: National Foreign Language Center, Johns Hopkins University.

Brumfit, C. (1997) Theoretical practice: applied linguistics as pure and practical science. In A. Mauranen \& K. Sajavaara (eds.), Applied linguistics across disciplines, (pp. 18-30). AILA Review, 12, 1995/6.

Butler, J. (1997) Excitable speech: a politics of the performative. London: Routledge.

Calvet, L. J. (1998) Language wars and linguistic politics. New York: Oxford University Press.

Chambers, J. K. (1995) Sociolinguistic theory. Oxford: Blackwell.

Christian, D., Montone, C. L., Lindholm, K. J., \& Carranza, I. (1997) Profiles in two-way immersion education. Washington, DC: Center for Applied Linguistics and Delta Systems.

Cooper, R. L. (1989) Language Planning and Social Change. Cambridge: Cambridge University Press.

Coulmas, F. (1989) Democracy and the crisis of normative linguistics. In F. Coulmas (ed.), Language Adaptations (pp. 177-93). Cambridge: Cambridge University Press.

Coulmas, F. (1994) Why is language standardisation necessary? Economic considerations. In National Language Institutes around the World, Diversity in Language Issues (pp. 172-201). Tokyo: National Language Research Institute.

Crawford, J. (1995) Bilingual education: history, politics, theory and practice. Los Angeles: Bilingual Education Services.

Crawford, J. (2000) At war with diversity: US immigration policy in an age of anxiety. Clevedon, UK: Multilingual Matters.

Dahlstedt, K. H. (1976) Societal ideology and language cultivation: the case of Swedish. International Journal of the Sociology of Language, 10, 17-50.

Davies, A. (1999) An Introduction to applied linguistics: from practice to theory. Edinburgh: 
Edinburgh University Press.

DeFrancis, J. (1977) Colonialism and Language Policy in Vietnam. The Hague: Mouton.

Dentith, S. (1995) Bakhtinian thought. London: Routledge.

de La Pena, F. (1991) Democracy or Babel? Washington DC: US English.

Djite, P. (1994) From language policy to immigration planning. Melbourne: Language Australia Publications.

Dua, H. R. (1985) Language-planning in India. New Delhi: Harnam Publications.

Dua, H. R. (1986) Language-planning and linguistic minorities In E. Annamalai, B. H. Jernudd, \& J. Rubin (eds.), Language planning: proceedings of an institute. (pp. 133-73). Mysore: Central Institute of Indian Languages; Hawai'i: Institute of Culture and Communications, East-West Center.

Eastman, C. M. (1983) Language-planning: An introduction. Novato, CA: Chandler \& Sharp.

Edelman, M. J. (1988) Constructing the political spectacle. Chicago and London: The University of Chicago Press.

Fairclough, N. (1989) Language and power. London: Longman.

Fairclough, N. (1995) Critical discourse analysis: the critical study of language. London: Longman.

Fasold, R. (1984) Sociolinguistics of society (vol. 1). Oxford: Blackwell.

Ferguson, C. A. (1979) National attitudes to language planning. In T. Huebner (ed.), Socio-linguistic perspectives: papers on language in society, 1959-1994 (pp. 295-303). New York: Oxford University Press.

Fishman J. A. (1971) The sociology of language. In J. A. Fishman (ed.), Advances in the sociology of language (vol. 1) (pp. 217-414). The Hague: Mouton.

Fishman, J. A. (ed.) (1974) Advances in language planning. The Hague: Mouton.

Fishman, J. A. (1973) Language modernization and planning in comparison with other types of national modernization and planning. Language in Society, 2(1), 23-44.

Fishman, J. A. (1994) Critiques of language planning: a minority languages perspective. Journal of Multilingualism and Multiculturalism Development, 15(2 \& 3), 91-9.

Fishman, J. A. (ed.) (2001) Can threatened languages be saved? Clevedon, UK: Multilingual Matters.

Foucault, M. (1979) Discipline and punish: the birth of the prison. New York: Vintage.

Gee, J. (1996) Sociolinguistics and literacy: ideology in discourse. London: The Falmer Press.

Gingrich, N. (1995) To renew America. New York: Harper Collins.

Gottlieb, N. \& Chen, P. (eds.) (2001) Language policy in East Asia: a reader. London: Curzon Press.

Halliday, M. A. K. (1993) Language in a changing world. Applied Linguistics Association of Australia; occasional paper 13. Canberra: Australian National University Printing Services.

Hanks, W. F. (1996) Language and communicative practices. Boulder, CO: Westview Press.

Haugen, E. (1966) Language conflict and language planning: the case of modern Norwegian. Cambridge, MA: Harvard University Press.

Heller, M. (1999) Linguistic minorities and modernity: a sociolinguistic ethnography. London and New York: Longman.

Hobsbawm, E. J. (1993) Nations and nationalism since 1780: programme, myth, reality. Cambridge: Canto.

Jernudd, B. H. (1973) Language planning as a type of language treatment. In J. Rubin \& R. Shuy (eds.), Language planning: current issues and research (pp. 11-23). Washington DC: Georgetown University Press.

Joseph, J.E. (1987) Eloquence and power: the rise of language standards and standard languages. London: Frances Pinter.

Juckes, T. J. (1995) Opposition in South Africa. Westport, CT: Praeger.

Kaplan, R. B. (1994) Language policy and planning: fundamental issues. Annual Review of Applied Linguistics, 14, 3-19.

Kloss, H. (1969) Research possibilities on group bilingualism. Quebec: International Center for Research on Bilingualism.

Le Page, R. B. (1988) Some premises concerning the standardization of languages with special 
reference to Caribbean Creole English. International Journal of the Sociology of Language, 71, 25-36.

Le Page, R. B. (1993) Language, economy and tolerance: an interview with Benigno Fernandez Salgado. MS: University of Oxford.

Le Page, R. B. \& Tabouret-Keller, A (1985) Acts of identity: Creole-based approaches to language and ethnicity. Cambridge: Cambridge University Press.

Lewis, G. (1999) The Turkish language reform: a catastrophic success. Oxford University Press.

Lo Bianco, J. (1999) Policy words: talking bilingual education and ESL into English literacy. Prospect, 14(2), 40-52.

Lo Bianco, J. (2001a) Vietnam: Quoc Ngu, colonialism, and language policy. In N. Gottlieb \& P. Chen (eds.), Language policy in East Asia: a reader (pp. 159-207). London: Curzon Press.

Lo Bianco, J. (2001b) Officialising language, a discourse study of language politics in the United States. Unpublished PhD thesis. Australian National University.

Lo Bianco, J. (ed.) (2002) Voices from Phnom Penh: language and development. Melbourne: Language Australia Publications.

Luke, A., McHoul, A. W., \& Mey, J. L. (1990) On the limits of language planning: class, state and power. In R. B. Baldauf, Jr. \& A. Luke (eds.), Language planning and education in Australasia and the South Pacific (pp. 25-44). Clevedon, UK: Multilingual Matters.

Mansour, G. (1993) Multilingualism and nation building. Clevedon, UK: Multilingual Matters.

McGroarty, M. (1997) Language policy in the USA: national values, local loyalties, pragmatic pressures. In W. Eggington \& H. Wren (eds.), Language policy: dominant english, pluralist challenges. Canberra: Language Australia; Amsterdam: John Benjamins.

Moore, H. M. (1996) Language policies as virtual realities: two Australian examples. TESOL Quarterly, 30(1) (Autum11), 473-97.

Mühlhäusler, P. (1995) Linguistic ecology, language change and linguistic imperialism in the Pacific region. London and New York: Routledge.

Nahir, M. (1984) Language planning goals: a classification. Language Problems and Language Planning, 8(3), 294-327.

Nettle, D. \& Romaine, S. (2000) Vanishing voices: the extinction of the world's languages. Oxford: Oxford University Press.

Neustupny, J. V. (1978) Post-structural approaches to language: language theory in a Japanese context. Tokyo: University of Tokyo Press.

Neustupny, J. V. (1983) Towards a paradigm for language planning. Language Planning Newsletter, 9(4).

Newmeyer, F. J. (1986) The politics of linguistics. Chicago: the University of Chicago Press.

Pattanayak, D. P. (1987) Multilingualism and multiculturalism: Britain and India, occasional paper no.1. London: International Association for Intercultural Education, Institute of Education, University of London.

Phillipson, R. \& Skutnabb-Kangas, T. (1996) English only worldwide or language ecology? TESOL Quarterly, 30, 429-52.

Pool, J. (1972) National development and language diversity. In J. A. Fishman (ed.), Advances in the sociology of language, vol. II: Selected studies and applications (pp. 213-30). The Hague: Mouton.

Pratt, M. L. (1987) Linguistic utopias. In N. Fabb, D. Attridge, D. Durant, \& C. McAbe (eds.), The linguistics of writing (pp. 49-66). Manchester: Manchester University Press.

Ricento, T. (2000) Historical and theoretical perspectives in language policy and planning. In T. Ricento (ed.), Ideology, politics and language policies: focus on English (pp. 9-25). Amsterdam: John Benjamins.

Rubin, J. \& Jernudd, B. H. (eds.) (1971) Can language be planned? Sociolinguistic theory and practice for developing nations. Honolulu: University of Hawai'i Press.

Schieffelin, B. B., Woolard, K. A., \& Kroskrity, P. V. (J 998) Language ideologies: practice and theory. New York: Oxford University Press. 
Schneider, S. G. (1976) Revolution, reaction or reform: the 1974 Bilingual Education Act. New York: LA Publishing Company.

Shannon, S. M. (1999) The debate on bilingual education in the US: language ideology as reflected in the practices of bilingual teachers. In J. Blommaert (ed.), Language ideological debates (pp. 171-201). Berlin: Mouton de Gruyter.

Skutnabb-Kangas, T. (1995) Multilingualism for all. Lisse, Netherlands: Swets \& Zeitlinger.

Sommer, B. A. (1991) Yesterday's experts: the bureaucratic impact on language planning for Aboriginal bilingual education. Australian Review of Applied Linguistics, Series S, 8, 109-35.

Tarver, H. (1989) Language and politics in the 1980s, the story of US English. Politics and Society, 17 (2), 220-39.

Tauli, V. (1984) The failure of language planning research. In A. Gonzalez (ed.), Language planning, implementation and evaluation: essays in honour of Bonifacio Sibayan. Manila: Linguistic Society of the Philippines.

Thompson, J. (1991) Introduction. In P. Bourdieu (ed.), Language and symbolic power (pp. 1-30). Cambridge, MA: Harvard University Press.

Tollefson, J. W. (1991) Planning language, planning inequality: language policy in the community. New York: Longman Cheshire.

Webb, V. (2002) Language in South Africa: the role of language in national transformation, reconstruction and development. Amsterdam: Benjamins.

\section{Further Reading}

Ager, D. (2001) Motivation in language planning and language policy. Clevedon, UK: Multilingual Matters.

Baker, S. (ed.) (2002) Language policy: lessons from global models. Monterey, CA: Monterey Institute for International Studies.

Crawford, J. (1999) Bilingual education, history, politics, theory and practice (4th edn.). Los Angeles; Bilingual Education Services.

Davis, K. A. (1994) Language planning in multilingual contexts. policies, communities and schools in Luxembourg. Amsterdam/ Philadelphia: John Benjamins.

Jaffe, A. (1999) Ideologies in action: language politics on Corsica. Berlin and New York: Mouton de Gruyter.

Lo Bianco, J. \& Wickert, R. (eds.) (2001) Australian policy Activism in language and literacy. Melbourne: Language Australia Publications. 


\section{University Library}

\section{- M M I N E R VA A gateway to Melbourne's research publications}

Minerva Access is the Institutional Repository of The University of Melbourne

Author/s:

Lo Bianco, J

Title:

Language Planning as Applied Linguistics

Date:

2008-01-21

Citation:

Lo Bianco, J. (2008). Language Planning as Applied Linguistics. DAVIES, AD (Ed.). ELDER, CE (Ed.). The Handbook of Applied Linguistics, (1), pp.738-762. Blackwell Publishing Ltd.

Persistent Link:

http://hdl.handle.net/11343/112608 